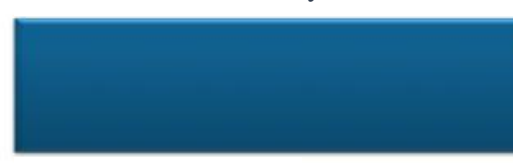

ISSN: 2717-736X

Cilt: 2 Say1: 4
19 MAYIS JOURNAL OF SOCLAL SCIENCES

19 MAYIS SOSY AL BILIMLER DERGISİ

Makale geliş tarihi : 11.09 .21

Makale kabul tarihi: 12.11 .21

\title{
NEWS AND CREDIT RATING AGENCY RELATED VOLATILITY ON TURKISH STOCK MARKET ${ }^{1}$
}

\author{
Arş. Gör. Fatih CİNGÖZ
}

Hitit University

Department of Finance and Banking

fatihcingoz@hitit.edu.tr

ORCID: 0000-0002-9425-7725

\author{
Arş. Gör. Dr. Mustafa NAL \\ Hitit University \\ Department of Economics \\ mustafanal@hitit.edu.tr
}

ORCID: 0000-0001-6190-6437

\begin{abstract}
The study aims to identify volatility in the banking sector and general market related to some different types of announcements. Totally 103 announcements are clustered considering their sentiment and source. Daily closing values of banking and market indices, XBANK and BIST100, are included in the dataset which spans from the beginning of January 2018 to the end of March 2019. Series of ordinary least squares (OLS) regressions are applied to evaluate the reaction of the indices to the announcements for each event type. Findings indicate that the banking sector is not affected by the announcements released by the government. Announcements of credit rating agencies carry an informative value and play an important role in volatility. Furthermore, the relationship between economic indicators and volatility exists for the national market. As an interesting finding, investors tend to react 2 days before to the announcements belonging to Standard \& Poor's and Fitch.
\end{abstract}

Keywords: Credit Rating Agency, Stock Market, BIST100, Announcements, News.

JEL Code: $G 24, G 15, G 4$

\footnotetext{
${ }^{1}$ This paper is an extended version of work presented in 2. International Banking Congress be held in Çorum on April 19, 2019.
} 


\title{
KREDİ DERECELENDİRME KURULUŞLARININ VE EKONOMİ İLE İLGILİ HABERLERİN HISSE SENEDİ PIYYASASINDA YARATTIĞI VOLATILITTE
}

\begin{abstract}
$\ddot{O} z$
Çalışmada toplam 103 haber, kaynakları ve yatırımcılar üzerinde yaratacağı beklentiler dikkate alınarak gruplandırılmıştır. Bu haberlerin BİST100 ve BİST Banka endeksleri üzerinde yarattığı etkiler araştırılmıştır. Ocak 2018 ve Mart 2019 arasındaki tarihte ilgili endekslerin günlük kapanış verileri dikkate alınmıştır. Bulgular, bankacılık sektörünün hükümetin yaptığı açıklamalardan etkilenmediğini göstermektedir. Öte yandan, kredi derecelendirme kuruluşlarının açıklamalarının bilgilendirici bir değer taşıdığı ve oynaklıkta önemli rol oynadığ bulunmuştur. Ayrıca, ulusal piyasa için ekonomik göstergeler ile oynaklık arasındaki ilişki mevcuttur. Yatırımcıların Standard \& Poor's ve Fitch'e ait duyurulara 2 gün öncesinden tepki verme eğiliminde oldukları gözlemlenmiştir.
\end{abstract}

Anahtar Kelimeler: Kredi Derecelendirme Kuruluşu, Borsa, BİST100, Duyurular, Haberler. JEL Code: $G 24, G 15, G 4$

\section{INTRODUCTION}

In financial markets, only new informations should call market participants to attention and make them reassess their investment decisions (Andersson et al., 2009). The price of financial assets may change due to the informational ratios or statistics released by governments or some other organizations statistics related with the economy (Bartolini et al.,2008). In addition, given the importance of rating agencies, announcements or events belonging to major rating agencies may have an impact on the financial markets and trigger a reaction (Norden\&Weber, 2004).

The paper aims to investigate whether the group of news and their sentiment have an impact on the indices of BIST100 and XBANK. The BIST100 index is chosen since it comprises the largest and most widely traded 100 stocks listed on the Borsa Istanbul from various sectors. The banking sector also has the highest weight in the Borsa Istanbul and represents the market's general attitude. Thus, these indices are the most convenient to analyse the effect of announcements.

In this study, the speed of the reaction by investors to these announcements is analysed rather than the size of that response. A set of news is clustered as different events and defined as good or bad news. Thus, we try to identify which type of released information makes a change in investors behaviour and trigger a reaction in the general market. Grouping the announcements by event type does not generate significant results. Then, we continue the study by examining the influence of announcements according to their source, separately. 103 news are tracked within the period of January 2018 to April $2019^{2}$. These announcements are divided into four categories. Motivated by the study of Kutan et al. (2011), we construct a schema including news. Table 1 shows clustering the news according to their sentiment and event type.

\footnotetext{
${ }^{2}$ There are some positive and negative news at the same day, thus, excluded from the analysis.
} 
Table 1: Event Types and News Summaries

\begin{tabular}{|c|c|c|c|}
\hline Date & $\begin{array}{l}\text { Even } \\
\mathrm{t} \\
\text { Type }\end{array}$ & $\begin{array}{l}\text { Good } \\
\& \\
\text { Bad } \\
\text { News }\end{array}$ & Summary \\
\hline $\begin{array}{l}25.03 .201 \\
9\end{array}$ & 4 & + & $\begin{array}{l}\text { The capacity utilization rate in the Turkish manufacturing } \\
\text { industry increased by } 0.4 \text { percentage points compared to the } \\
\text { previous month. }\end{array}$ \\
\hline $\begin{array}{l}23.03 .201 \\
9\end{array}$ & 3 & - & $\begin{array}{l}\text { Fitch Ratings expects a negative growth rate in Turkish } \\
\text { economy by } 1.1 \% \text { for the year of } 2019 \text {. }\end{array}$ \\
\hline $\begin{array}{l}21.03 .201 \\
9\end{array}$ & 4 & + & $\begin{array}{l}\text { Consumer confidence index increased by } 2.8 \% \text { compared to the } \\
\text { previous month. }\end{array}$ \\
\hline $\begin{array}{l}20.03 .201 \\
9\end{array}$ & 3 & - & $\begin{array}{l}\text { Moody's upgraded the external vulnerability risk of Turkey from } \\
\text { "high" to "high +". }\end{array}$ \\
\hline $\begin{array}{l}15.03 .201 \\
9\end{array}$ & 3 & + & $\begin{array}{l}\text { Moody's reported that lowering of the interest limit on deposits } \\
\text { held by public institutions in state banks is "positive" for the } \\
\text { credit ratings of the state banks. }\end{array}$ \\
\hline $\begin{array}{l}13.03 .201 \\
8\end{array}$ & 3 & - & $\begin{array}{l}\text { Fitch Ratings reported downward revision for Turkey's potential } \\
\text { growth rate decreased by } 0.5 \mathrm{pp} \text { and it is forecasted as } 4.3 \\
\text { percent now. }\end{array}$ \\
\hline 8.03 .2019 & 1 & + & $\begin{array}{l}\text { The Minister of Treasury and Finance stated that the Istanbul } \\
\text { Finance Center project will be implemented before } 2023 \text {. }\end{array}$ \\
\hline 4.03 .2019 & 4 & - & $\begin{array}{l}\text { The Consumer Price Index rose by } 1.0 \% \text { within the recent } \\
\text { month. }\end{array}$ \\
\hline 1.03 .2019 & 2 & + & $\begin{array}{l}\text { The banking sector survived the hard times due to the high } \\
\text { volatility in exchange and interest rate and the banking stocks } \\
\text { have attracted foreign investors again. }\end{array}$ \\
\hline $\begin{array}{l}22.02 .201 \\
9\end{array}$ & 4 & - & $\begin{array}{l}\text { Manufacturing capacity utilization rate decreased } 0.5 \% \text { over the } \\
\text { previous month. }\end{array}$ \\
\hline $\begin{array}{l}20.02 .201 \\
9\end{array}$ & 4 & - & $\begin{array}{l}\text { Over the last month, consumer confidence index declined by } \\
1 \% \text {. }\end{array}$ \\
\hline $\begin{array}{l}19.02 .201 \\
9\end{array}$ & 3 & - & $\begin{array}{l}\text { Standard \& Poor's (S\&P) assessed that the Turkish lira will } \\
\text { depreciate steadily over the next three years. }\end{array}$ \\
\hline $\begin{array}{l}18.02 .201 \\
9\end{array}$ & 2 & + & $\begin{array}{l}\text { According to banks, the decrease in deposit rates will continue } \\
\text { with small steps. }\end{array}$ \\
\hline
\end{tabular}




\begin{tabular}{|c|c|c|c|}
\hline 4.02 .2019 & 4 & - & $\begin{array}{l}\text { The Consumer Price Index soared by } 0.2 \% \text { compared to the last } \\
\text { month. }\end{array}$ \\
\hline 1.02 .2019 & 2 & + & $\begin{array}{l}\text { In } 2018 \text {, the banking sector dominated Turkey's top ten most } \\
\text { valuable brands. Five banks took place in the list. }\end{array}$ \\
\hline $\begin{array}{l}25.01 .201 \\
9\end{array}$ & 4 & + & $\begin{array}{l}\text { Over the last month, the capacity utilization rate in the } \\
\text { manufacturing industry increased by } 0.4 \% \text {. }\end{array}$ \\
\hline $\begin{array}{l}23.01 .201 \\
9\end{array}$ & 4 & + & $\begin{array}{l}\text { Consumer confidence index increased by } 0.5 \% \text { over the } \\
\text { previous month. }\end{array}$ \\
\hline $\begin{array}{l}17.01 .201 \\
9\end{array}$ & 2 & + & $\begin{array}{l}\text { The credit volume in the banking sector increased by } 13 \text { billion } \\
83 \text { million liras last week. }\end{array}$ \\
\hline $\begin{array}{l}14.01 .201 \\
9\end{array}$ & 4 & - & $\begin{array}{l}\text { Over the last month, Turkey's calendar-adjusted industrial } \\
\text { production decreased by } 14 \% \text {. }\end{array}$ \\
\hline 3.01 .2019 & 4 & - & Over the last month, consumer price index increased $1.1 \%$. \\
\hline $\begin{array}{l}27.12 .201 \\
8\end{array}$ & 2 & - & $\begin{array}{l}\text { The high interest rates and the recent slowing in the pace of } \\
\text { credit growth has affected the sale of non-performing loans. } \\
\text { There was a serious shrinking in the 'bad loans' market this year. }\end{array}$ \\
\hline $\begin{array}{l}21.12 .201 \\
8\end{array}$ & 4 & - & $\begin{array}{l}\text { Consumer confidence index decreased by } 2.3 \% \text { compared to the } \\
\text { previous month. }\end{array}$ \\
\hline 5.12 .2018 & 1 & + & $\begin{array}{l}\text { The research about the digital maturity of the banking sector, } \\
\text { which includes } 238 \text { banks and } 10 \text { FinTech institutions in } 38 \\
\text { countries, showed that Turkey was among the top } 5 \text { countries. }\end{array}$ \\
\hline 3.12 .2018 & 4 & + & $\begin{array}{l}\text { Consumer price index decreased by } 0.4 \text { percent compared to the } \\
\text { previous month. }\end{array}$ \\
\hline $\begin{array}{l}26.11 .201 \\
8\end{array}$ & 4 & - & $\begin{array}{l}\text { The capacity utilization rate in the manufacturing industry } \\
\text { decreased by } 1.7 \% \text { compared to the previous month. }\end{array}$ \\
\hline $\begin{array}{l}22.11 .201 \\
8\end{array}$ & 4 & + & $\begin{array}{l}\text { Consumer confidence index increased by } 4 \% \text { compared to the } \\
\text { previous month. }\end{array}$ \\
\hline $\begin{array}{l}16.11 .201 \\
8\end{array}$ & 4 & - & $\begin{array}{l}\text { Seasonally and calendar adjusted industrial production } \\
\text { decreased by } 3 \% \text { compared to the previous month. }\end{array}$ \\
\hline $\begin{array}{l}15.11 .201 \\
8\end{array}$ & 3 & - & $\begin{array}{l}\text { Fitch has downgraded the growth forecasts of Turkey for the } \\
\text { years of and } 2018 \text { and } \\
\text { Fitch noted that the factors like exchange rate crisis, high } \\
\text { inflation rates and challenging external financing conditions } \\
\text { may lead to a recession in } 2019 \text {. }\end{array}$ \\
\hline
\end{tabular}




\begin{tabular}{|c|c|c|c|}
\hline $\begin{array}{l}15.11 .201 \\
8\end{array}$ & 4 & - & $\begin{array}{l}\text { The unemployment rate increased by } 6 \% \text { compared to the } \\
\text { previous month. }\end{array}$ \\
\hline 6.11 .2018 & 1 & - & $\begin{array}{l}\text { The Banks Association of Turkey reported that employment in } \\
\text { the banking sector decreased by } 721 \text { people at the end of } \\
\text { September compared to the same period of the last year. }\end{array}$ \\
\hline 5.11 .2018 & 4 & + & $\begin{array}{l}\text { Consumer price index decreased by } 1.4 \text { percent compared to the } \\
\text { previous month. }\end{array}$ \\
\hline $\begin{array}{l}30.10 .201 \\
8\end{array}$ & 2 & + & $\begin{array}{l}\text { Interest rate drops with the measures taken by the management } \\
\text { and the fall in the country risk premia. }\end{array}$ \\
\hline $\begin{array}{l}25.10 .201 \\
8\end{array}$ & 4 & - & $\begin{array}{l}\text { The capacity utilization rate in the manufacturing industry } \\
\text { decreased by } 1 \% \text { compared to the previous month. }\end{array}$ \\
\hline $\begin{array}{l}25.10 .201 \\
8\end{array}$ & 2 & - & $\begin{array}{l}\text { Higher accounts receivable turnover ratio and increased demand } \\
\text { for bankruptcy are expected to stress the banking sector. }\end{array}$ \\
\hline $\begin{array}{l}23.10 .201 \\
8\end{array}$ & 4 & - & $\begin{array}{l}\text { Consumer confidence index decreased by } 3.4 \text { percent compared } \\
\text { to the previous month. }\end{array}$ \\
\hline $\begin{array}{l}16.10 .201 \\
8\end{array}$ & 4 & + & $\begin{array}{l}\text { Seasonally and calendar adjusted industrial production } \\
\text { increased by } 4 \% \text { compared to the previous month. }\end{array}$ \\
\hline $\begin{array}{l}16.10 .201 \\
8\end{array}$ & 1 & + & $\begin{array}{l}\text { Foreign investors stated that Turkey, a member of the G20, is an } \\
\text { important country for the world and the region, has a high } \\
\text { potential, and they have confidence in the long-term } \\
\text { performance of the Turkish economy. }\end{array}$ \\
\hline $\begin{array}{l}15.10 .201 \\
8\end{array}$ & 4 & - & $\begin{array}{l}\text { The unemployment rate increased by } 1.8 \text { percent compared to } \\
\text { the previous month. }\end{array}$ \\
\hline $\begin{array}{l}11.10 .201 \\
8\end{array}$ & 4 & + & $\begin{array}{l}\text { Turkey's current account balance showed a surplus of } \$ 2.592 \\
\text { billion in August. }\end{array}$ \\
\hline 5.10 .2018 & 2 & + & $\begin{array}{l}\text { Gold deposit accounts of residents in Banks increased by } 15.2 \\
\text { billion liras in August compared to the same period of the } \\
\text { previous year. }\end{array}$ \\
\hline 3.10 .2018 & 4 & - & Consumer price index increased by $2.7 \%$ over the recent month. \\
\hline 2.10 .2018 & 3 & - & $\begin{array}{l}\text { Fitch downgraded the long-term foreign currency credit ratings } \\
\text { of } 20 \text { Turkish banks and their subsidiaries. }\end{array}$ \\
\hline $\begin{array}{l}24.09 .201 \\
8\end{array}$ & 4 & - & $\begin{array}{l}\text { The capacity utilization rate of the manufacturing industry } \\
\text { decreased by } 2.1 \text { percentage points compared to the previous } \\
\text { month. }\end{array}$ \\
\hline
\end{tabular}




\begin{tabular}{|c|c|c|c|}
\hline $\begin{array}{l}20.09 .201 \\
8\end{array}$ & 4 & - & $\begin{array}{l}\text { Consumer confidence index decreased by } 13.2 \% \text { compared to } \\
\text { the last month. }\end{array}$ \\
\hline $\begin{array}{l}18.09 .201 \\
8\end{array}$ & 1 & + & $\begin{array}{l}\text { World Bank Group institution, IFC, made a long-term } \\
\text { investment of } 1.1 \text { billion dollars in Turkey in the first } 6 \text { months } \\
\text { of } \\
\text { Turkey is currently the second country in which IFC has } \\
\text { invested the most in the world. }\end{array}$ \\
\hline $\begin{array}{l}11.09 .201 \\
8\end{array}$ & 3 & + & $\begin{array}{l}\text { Moody's reported that most Turkish companies can cope with } \\
\text { refinancing risks despite increased uncertainties. }\end{array}$ \\
\hline $\begin{array}{l}10.09 .201 \\
8\end{array}$ & 2 & - & $\begin{array}{l}\text { The amount of interest paid by banks on deposits increased by } \\
40.8 \text { percent at the end of July compared to the same month of } \\
2017 \text { and exceeded } 70 \text { billion liras. }\end{array}$ \\
\hline 3.09 .2018 & 4 & - & $\begin{array}{l}\text { Over the previous month, consumer price index increased by } \\
6.30 \text { percent. }\end{array}$ \\
\hline 3.09 .2018 & 2 & + & $\begin{array}{l}\text { The loan volume of the banking sector increased by } 6 \text { billion } \\
597 \text { million TL. }\end{array}$ \\
\hline $\begin{array}{l}27.08 .201 \\
8\end{array}$ & 4 & + & $\begin{array}{l}\text { Over the recent month, the capacity utilization rate in the } \\
\text { manufacturing industry increased by } 0.9 \text { percentage points. }\end{array}$ \\
\hline $\begin{array}{l}27.08 .201 \\
8\end{array}$ & 2 & + & $\begin{array}{l}\text { The asset size of the } 10 \text { deposit banks traded in the stock market } \\
\text { increased by } 246.3 \text { billion liras in six months and exceeded } 2.4 \\
\text { trillion liras. }\end{array}$ \\
\hline $\begin{array}{l}17.08 .201 \\
8\end{array}$ & 3 & - & $\begin{array}{l}\text { Standard \& Poor's (S\&P) downgraded Turkey's foreign } \\
\text { currency credit rating from BB- to B+. }\end{array}$ \\
\hline $\begin{array}{l}17.08 .201 \\
8\end{array}$ & 4 & - & $\begin{array}{l}\text { Over the last month, consumer confidence index decreased by } \\
6.6 \text { percent. }\end{array}$ \\
\hline $\begin{array}{l}16.08 .201 \\
8\end{array}$ & 4 & - & $\begin{array}{l}\text { Over the last month, seasonally and calendar adjusted industrial } \\
\text { production decreased by } 17 \text { percent. }\end{array}$ \\
\hline $\begin{array}{l}16.08 .201 \\
8\end{array}$ & 1 & + & $\begin{array}{l}\text { The Minister of Economy gave the message to foreign investors } \\
\text { that they fully understand and realize all the difficulties in the } \\
\text { country and their first priority is to reduce inflation. }\end{array}$ \\
\hline $\begin{array}{l}15.08 .201 \\
8\end{array}$ & 4 & - & $\begin{array}{l}\text { Over the last month, the unemployment rate increased by } 3.3 \\
\text { percent. }\end{array}$ \\
\hline $\begin{array}{l}15.08 .201 \\
8\end{array}$ & 1 & - & $\begin{array}{l}\text { The Central Bank is squeezing TL liquidity. The CBRT did not } \\
\text { open the weekly repo auction, and short term interest rates } \\
\text { increased in foreign exchange auctions. }\end{array}$ \\
\hline
\end{tabular}




\begin{tabular}{|c|c|c|c|}
\hline 3.08 .2018 & 4 & - & $\begin{array}{l}\text { Over the last month, consumer price index increased by } 2.30 \\
\text { percent. }\end{array}$ \\
\hline $\begin{array}{l}31.07 .201 \\
8\end{array}$ & 2 & + & $\begin{array}{l}\text { Total asset size of the Turkish banking sector increased to } 3 \\
\text { trillion } 671 \text { billion } 537 \text { million liras in June. }\end{array}$ \\
\hline $\begin{array}{l}25.07 .201 \\
8\end{array}$ & 4 & - & $\begin{array}{l}\text { The capacity utilization rate of the manufacturing industry } \\
\text { decreased by } 1.5 \text { percentage points compared to the previous } \\
\text { month. }\end{array}$ \\
\hline $\begin{array}{l}24.07 .201 \\
8\end{array}$ & 4 & + & $\begin{array}{l}\text { Consumer confidence index increased by } 4 \% \text { compared to the } \\
\text { previous month. }\end{array}$ \\
\hline $\begin{array}{l}20.07 .201 \\
8\end{array}$ & 2 & + & $\begin{array}{l}\text { In parallel with the increase in financial literacy, the advantages } \\
\text { of card payments and the widespread use of e-commerce, card } \\
\text { payments increased by } 20 \text { percent in the first } 6 \text { months of this } \\
\text { year, reaching } 380 \text { billion TL. }\end{array}$ \\
\hline $\begin{array}{l}19.07 .201 \\
8\end{array}$ & 2 & + & $\begin{array}{l}\text { The total deposits in the banking sector rose to TL } 2 \text { trillion } 3 \\
\text { billion as of July. }\end{array}$ \\
\hline $\begin{array}{l}17.07 .201 \\
8\end{array}$ & 4 & + & $\begin{array}{l}\text { Over the last month, seasonally and calendar adjusted industrial } \\
\text { production increased by } 12.8 \% \text {. }\end{array}$ \\
\hline $\begin{array}{l}16.07 .201 \\
8\end{array}$ & 4 & - & $\begin{array}{l}\text { Over the last month, the unemployment rate increased by } 5.9 \\
\text { percent. }\end{array}$ \\
\hline $\begin{array}{l}13.07 .201 \\
8\end{array}$ & 3 & - & $\begin{array}{l}\text { Fitch Ratings downgraded Turkey's credit rating from "BB+" to } \\
\text { "BB" and revised outlook as "negative". }\end{array}$ \\
\hline 6.07 .2018 & 2 & + & $\begin{array}{l}\text { Gold accounts in banks were recorded as the highest level of all } \\
\text { time! }\end{array}$ \\
\hline 3.07 .2018 & 4 & - & $\begin{array}{l}\text { Over the last month, consumer price index increased by } 0.6 \\
\text { percent. }\end{array}$ \\
\hline 2.07 .2018 & 2 & - & $\begin{array}{l}\text { Interest rates have experienced upward momentum and, as of } \\
\text { June, reached the peak of } 9.5 \text { years. }\end{array}$ \\
\hline $\begin{array}{l}28.06 .201 \\
8\end{array}$ & 2 & + & The credit volume of the banking sector has increased. \\
\hline $\begin{array}{l}25.06 .201 \\
8\end{array}$ & 4 & + & $\begin{array}{l}\text { Over the last month, the capacity utilization rate in the } \\
\text { manufacturing industry increased by } 0.5 \text { percentage points. }\end{array}$ \\
\hline $\begin{array}{l}22.06 .201 \\
8\end{array}$ & 2 & + & $\begin{array}{l}\text { The transaction record was broken in interbank card transaction } \\
\text { traffic on the eve of the religious festival. On that day, the } \\
\text { amount of } 2.5 \text { billion liras payments were made by credit card. }\end{array}$ \\
\hline
\end{tabular}




\begin{tabular}{|c|c|c|c|}
\hline $\begin{array}{l}21.06 .201 \\
8\end{array}$ & 4 & + & $\begin{array}{l}\text { Over the last month, consumer confidence index increased by } \\
0.6 \% \text {. }\end{array}$ \\
\hline $\begin{array}{l}18.06 .201 \\
8\end{array}$ & 4 & - & $\begin{array}{l}\text { Over the last month, the unemployment rate increased by } 4.7 \\
\text { percent. }\end{array}$ \\
\hline $\begin{array}{l}18.06 .201 \\
8\end{array}$ & 2 & - & $\begin{array}{l}\text { Short-term external debt stock reached } 125.5 \text { billion dollars at } \\
\text { the end of April and reached the highest level of the last } 2.5 \\
\text { years. }\end{array}$ \\
\hline $\begin{array}{l}13.06 .201 \\
8\end{array}$ & 4 & - & $\begin{array}{l}\text { Over the last month, seasonally and calendar adjusted industrial } \\
\text { production decreased by } 11 \% \text {. }\end{array}$ \\
\hline 8.06 .2018 & 1 & + & $\begin{array}{l}\text { Although the ratings of } 17 \text { Turkish banks were downgraded by } \\
\text { Moody's, The Deputy Prime Minister stated that the banking } \\
\text { sector remained healthy and solid. He also stated that the capital } \\
\text { adequacy ratio is } 15 \% \text { despite the recent increase in interest } \\
\text { rates. }\end{array}$ \\
\hline 4.06 .2018 & 1 & + & $\begin{array}{l}\text { Venture capital funds, reaching } \$ 320 \text { billion worldwide, will be } \\
\text { encouraged to open offices in Turkey and establish partnerships } \\
\text { with domestic funds. }\end{array}$ \\
\hline 4.06 .2018 & 4 & - & $\begin{array}{l}\text { Over the last month, consumer price index increased by } 2.6 \\
\text { percent. }\end{array}$ \\
\hline $\begin{array}{l}25.05 .201 \\
8\end{array}$ & 4 & + & $\begin{array}{l}\text { Over the last month, the capacity utilization rate in the } \\
\text { manufacturing industry increased by } 0.8 \% \text {. }\end{array}$ \\
\hline $\begin{array}{l}23.05 .201 \\
8\end{array}$ & 4 & - & $\begin{array}{l}\text { Over the last month, consumer confidence index decreased by } \\
2.8 \% \text {. }\end{array}$ \\
\hline $\begin{array}{l}16.05 .201 \\
8\end{array}$ & 4 & + & $\begin{array}{l}\text { Over the last month, ceasonally and calendar adjusted industrial } \\
\text { production increased by } 5 \text { percent. }\end{array}$ \\
\hline $\begin{array}{l}16.05 .201 \\
8\end{array}$ & 1 & + & $\begin{array}{l}\text { The Banks Association of Turkey stated that the banking sector } \\
\text { has the structure and strong fundamentals to maintain a positive } \\
\text { outlook by managing risks properly." }\end{array}$ \\
\hline $\begin{array}{l}15.05 .201 \\
8\end{array}$ & 3 & - & $\begin{array}{l}\text { Moody's stated that the asset quality of Turkish banks was } \\
\text { expected to weaken. The reasons behind this remark are the } \\
\text { difficult operating environment, weakening construction } \\
\text { industry, and financial difficulties experienced by the banks } \\
\text { having higher debts. }\end{array}$ \\
\hline $\begin{array}{l}15.05 .201 \\
8\end{array}$ & 4 & - & Over the last month, the unemployment rate increased by $1 \%$. \\
\hline
\end{tabular}




\begin{tabular}{|c|c|c|c|}
\hline $\begin{array}{l}10.05 .201 \\
8\end{array}$ & 1 & + & $\begin{array}{l}\text { With the proposal adopted in the General Assembly of the } \\
\text { Grand National Assembly of Turkey, it is said that only } 2 \\
\text { percent of the assets brought from abroad will be collected as } \\
\text { tax. }\end{array}$ \\
\hline 3.05 .2018 & 4 & - & $\begin{array}{l}\text { Over the last month, consumer price index increased by } 1.6 \\
\text { percent. }\end{array}$ \\
\hline $\begin{array}{l}24.04 .201 \\
8\end{array}$ & 4 & - & $\begin{array}{l}\text { The capacity utilization rate in the manufacturing industry } \\
\text { decreased by } 0.6 \% \text { compared to the previous month. }\end{array}$ \\
\hline $\begin{array}{l}20.04 .201 \\
8\end{array}$ & 4 & + & $\begin{array}{l}\text { Over the last month, consumer confidence index increased by } \\
0.8 \% \text {. }\end{array}$ \\
\hline $\begin{array}{l}16.04 .201 \\
8\end{array}$ & 4 & - & $\begin{array}{l}\text { Over the last month, seasonally and calendar adjusted industrial } \\
\text { production decreased by } 5 \text { percent. }\end{array}$ \\
\hline $\begin{array}{l}10.04 .201 \\
8\end{array}$ & 1 & + & $\begin{array}{l}\text { According to the Ernst \& Young report, banking institutions } \\
\text { operating in Turkey will enhance their technology investment } \\
\text { budgets by } 27.8 \text { percent in the next } 12 \text { months. }\end{array}$ \\
\hline 3.04 .2018 & 4 & - & $\begin{array}{l}\text { Over the last month, consumer price index increased by } 1.9 \\
\text { percent. }\end{array}$ \\
\hline $\begin{array}{l}20.03 .201 \\
8\end{array}$ & 4 & - & $\begin{array}{l}\text { Over the last month, consumer confidence index decreased by } \\
1.4 \% \text {. }\end{array}$ \\
\hline $\begin{array}{l}16.03 .201 \\
8\end{array}$ & 4 & + & $\begin{array}{l}\text { Over the last month, seasonally and calendar adjusted industrial } \\
\text { production increased by } 14 \text { percent. }\end{array}$ \\
\hline $\begin{array}{l}15.03 .201 \\
8\end{array}$ & 4 & + & $\begin{array}{l}\text { Over the last month, the unemployment rate decreased by } 4.9 \\
\text { percent. }\end{array}$ \\
\hline 5.03 .2018 & 4 & - & $\begin{array}{l}\text { Consumer price index increased by } 1 \% \text { compared to the } \\
\text { previous month. }\end{array}$ \\
\hline $\begin{array}{l}22.02 .201 \\
8\end{array}$ & 4 & - & $\begin{array}{l}\text { Capacity utilization rate in the manufacturing industry } \\
\text { decreased by } 0.5 \text { percentage points compared to the previous } \\
\text { month. }\end{array}$ \\
\hline $\begin{array}{l}15.02 .201 \\
8\end{array}$ & 4 & + & $\begin{array}{l}\text { Over the last month, unemployment rate decreased by } 1.5 \\
\text { percent. }\end{array}$ \\
\hline $\begin{array}{l}13.02 .201 \\
8\end{array}$ & 2 & - & $\begin{array}{l}\text { The lowest mortgage rate offered by banks to consumers } \\
\text { reached the highest figure of the last } 20 \text { months, } 1.15 \% \text { per } \\
\text { month. }\end{array}$ \\
\hline $\begin{array}{l}12.02 .201 \\
8\end{array}$ & 3 & - & $\begin{array}{l}\text { S\&P stated that the main weakness of Turkish banks for this } \\
\text { year is funding and asset quality, and announced that the } \\
\text { profitability of banks is expected to decline in } 2018 \text {. }\end{array}$ \\
\hline
\end{tabular}




\begin{tabular}{|l|l|l|l|}
\hline 8.02 .2018 & 4 & - & $\begin{array}{l}\text { Over the last month, seasonally and calendar adjusted industrial } \\
\text { production decreased by } 3 \text { percent. }\end{array}$ \\
\hline 5.02 .2018 & 4 & - & Over the last month, consumer price index increased by $0.7 \%$. \\
\hline 2.02 .2018 & 1 & - & $\begin{array}{l}\text { According to the Turkish Banks Association data, the number } \\
\text { of employees in the banking sector decreased by } 3,195 .\end{array}$ \\
\hline
\end{tabular}

EventType:

(1) Covers the announcements, belonging to the Government or other institutions, linked to the general economy and banks.

(2)Covers the news directly associated with the banking sector. (3) Covers the announcements belonging to the three rating agencies: S\&P, Moody's and Fitch

Ratings.

(4) Covers the news concerning the economic data.

We define the news as positive if it is expected to lead better market sentiment, and classify as negaive if it builds an adverse market condition. Table 2 presents the numbers of classified positive and negative info included in each event category.

Table 2: Numbers Of Good And Bad News for Each Event Category

\begin{tabular}{|l|l|l|}
\hline Event Category & & No. of cases \\
\hline $\begin{array}{l}\text { (1) Belonging to the Government or other institutions, } \\
\text { linked to the general economy and banks. }\end{array}$ & Good news & 10 \\
\cline { 2 - 3 } & Bad News & 3 \\
\hline \multirow{2}{*}{ (2) News directly associated with the banking sector. } & Good news & 14 \\
\cline { 2 - 3 } & Bad News & 6 \\
\hline (3) Belonging to the three rating agencies: Standard \& & Good news & 2 \\
\cline { 2 - 3 } Poor's, Moody's and Fitch Ratings. & Bad News & 10 \\
\hline (4) Data concerning the economic indicators. & Good news & 20 \\
\cline { 2 - 3 } & Bad News & 38 \\
\hline
\end{tabular}

The event type related to the economic data includes the indicators as the Index of Consumer Confidence, Unemployment rate, Consumer Prices Index, the Capacity Utilization Rate of the Manufacturing Industry and the Industrial Production Index.

\section{LITERATURE REVIEW}

The effect of announcements on the financial market has attracted attention of some researchers. One of the studies related to this topic belongs to Balduzzi et al. (2001), which investigated the 
26 scheduled macroeconomic announcements to discover whether these cause a shift in U.S. Bond Market in terms of volume, bid-ask spreads and prices. They show evidence of increased volatility and trading volume immediately after announcements. Bid-ask spreads become larger with released announcements and reversing to normality takes at least five minutes after announcements.

Examining the release of six macroeconomic data, Kim et al. (2003) find that the reaction of stock, bond and currency markets is significantly stronger when there is a gap between expected and actual value for data. Investors in the currency market more actively screen the news about balance of trade while bond traders revise their strategies more with regards to internal economy news. Considering forecasted and actual values of macroeconomic indicators, the study of Green (2004) shows evidence about the role of asymmetric information on the US Bond Market. Following release, the immediate effect of asymmetric information is clear and back to it's normal in fifteen minutes. The increase in trading activity lasts for several hours following public release according to the results of this study.

Herath and Goonatilake (2007) study the influence of news over DJIA, NASDAQ and S\&P 500. The study covers a ten week period and reports a relationship between covered news and fluctuations of three dominant markets. Bartolini et al. (2008) investigate the change in stock prices, bond values and currencies surrounding the release of information. A series of ordinary least squares (OLS) regressions is used and the bond market is found as responding to released information happens more severely than any other markets while stock prices show relatively weaker response to the news. When the actual value of inflation and growth rate is more than expected, dollar and bond yields show significant rise.

Kosmidou et al. (2015) examined the efficiency of troika bailout programs concerning a wide range of news related to the Greek sovereign crisis. Their findings indicate that the banking sector is more prone to government-related news than financial and real economy sectors. The effects of ratings agencies-related news is significant for banking and real economy sectors according to their results.

Sarigül (2015) applied event study methodology to examine the effects of syndication loan announcements on the banking sector. The data covers the period of 2006-2013, 14 bank stocks and 87 announcements. The results do not provide statistically significant change in returns of bank stocks following loan announcements. The other study for Borsa Istanbul applied event study methodology is performed by Eyuboglu and Bulut (2015). They collected the news related to 30 stocks, having the biggest market capitalization, traded in the BIST30 index. The news are clustered into five categories. Statistically significant average abnormal returns are detected before and after the announcements release which imply that Borsa Istanbul is not effective at semi-strong form.

Byström (2016) presents a comprehensive study collecting more than nine millions news from Google. The result of the paper documented strong evidence related to the link between news and volatility.

The study focused on the impact of macroeconomic news belonging to both the US and Turkey 
(Gok\&Topuz, 2016) reports that volatility of Turkish Stock Market increases only by news about GDP of countries. In their analysis, they used the GARCH model and daily data. Their findings suggest no significant impact of news in overall.

Pirgaip (2017) analyzed the impact of action taken by sovereign credit ratings on Turkish Stock Market. The paper suggests that the equity market reacts to the reports of credit agencies prior to announcements and the reaction lasts only a few days following announcements, however, the market overreacts more to negative reports than positive ones. The study of Avci and Gursoy (2017) shows similar evidence to that of Pirgaip (2017) with related to magnitude effects of sovereign credit agencies on Turkish Stock Market as investors overreact more to downgrade announcements. But overall, they report that the impact of credit agencies is not significant.

Ekinci et al. (2019) investigated how US macroeconomic news releases affected the Turkish Stock Market in the short run. They use intraday data and analyse within 5 minute intervals. Volatility gets higher following the release, however, trading volume decreases within the next five minute following release according to their results. Moreover, their findings point out to generally negative returns after release.

One of the recent studies about how macroeconomic news has impacts on BIST belongs to Çekiç and Gültekin (2020). They present significant results for some sectoral indices in terms of volatility and abnormal returns by taking into GDP and PMI datas of Turkey, Us, Euro Zone and China. Uslu and Uzkaralar (2020) analyse the causal relationship between BIST100 and MBONCU indices in a monthly basis. Their findings point out a positive correlation between two variables.

\section{METHODOLOGY \& DATA}

The closing values of XBANK and BIST100 indices on a daily basis, within the period from January 2018 to April 2019, forms the dataset. The dataset related to the indices is generated from the Data Stream. We construct the data of announcements by the help of the Finnet program.

We calculated the daily returns as the natural logarithm of the ratio of successive closing values of indices.

$$
R_{i}=\log \left(\frac{P_{i}}{P_{i-1}}\right)
$$

$\mathrm{i}=\mathrm{XBANK}, \mathrm{BIST} 100$.

Then, we run a series of ordinary least squares (OLS) regressions to evaluate the reaction of the indices to the announcements for each event type. The equation 2 and 3 are used for the analysis:

$$
\begin{aligned}
& \text { lnbist }_{t}=\alpha+\beta_{0} \text { lnbist }_{t-1}+\sum_{i=j=1}^{k, n} \beta_{i j} \text { news }_{i j} \\
& \text { lnbank }_{t}=\alpha+\beta_{0} \text { lnbank }_{t-1}+\sum_{i=j=1}^{k, n} \beta_{i j} \text { news }_{i j}
\end{aligned}
$$

$\mathrm{i}=$ Moody's, S\&P, CPI, .......

$\mathrm{j}=$ time 


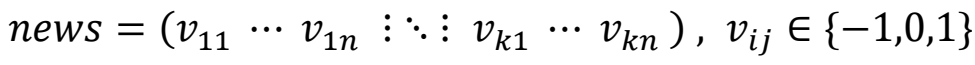

In case of a positive event, $\mathrm{V}$ takes value of 1 . If an event is expected to lead negative sentiment, then $\mathrm{V}$ takes the value of -1 . Otherwise, $\mathrm{V}$ is set to 0 .

Firstly, we try to figure out which event type has a significant effect on indices values. Clustering the events did not generate significant results to explain volatility in indices. Thus, we proceed the study by adding the announcements into the model separately according to their source. We focus on whether scheduled data related to the corresponding economic indicators and information announced by three credit rating agencies influence the stock price in two indices. We also examine whether these announcements are utilized by investors as leading or lagging guide. It should be noted that the announcements related to the economic indicators are scheduled on a monthly basis and the terms of good and bad refer to the sentiment of investors. For example, an increase in the unemployment rate has a negative impression on the economy, therefore, is defined as bad news in this study. On the other hand, a decrease in the unemployment rate is perceived as good news. Announcements of Industrial Production Index and Capacity Utilization Rate of the Manufacturing Industry are defined as positive if they experience an increase and vice versa. The data of monthly Consumer Prices Index (CPI) which has an impact on the average annual inflation rate are interpreted as negative if it exhibits an increase and vice versa. In this study, the calculations are made by the help of $\mathrm{R}$ programming.

\section{RESULTS}

We consider min-t criteria to see the presence of any structural breaks in the dataset. There are two days, where the $t$ statistic is minimized, in the data. The days where the structural break occurred are 18 April 2018 for BIST 100 and 05 April 2018 for BIST Banking Index. To capture the structural breaks, we include dummy variables into the model.

The estimated results from OLS regression are presented in Table 3. The reaction in the BIST100 and XBANK to the announcements related to the economic indicators and three credit rating agencies is summarized in the left and right panel, respectively.

In the Table 3, $q$ defines the announcements related with Manufacturing Industry, $\pi$ represents the announcements related to CPI. News data concerning unemployment rate is represented by $u$, whereas $d$ indicates the dummy variables.

Findings suggest that the announcements related to the unemployment rate have an instant effect on the market and explain the volatility in the BIST100 index. Thus, it can be inferred that market participants actively watch the info about the unemployment rate and are aware of the important role of this rate. The market responds with one day lag to news related to the manufacturing industry while the response to inflation rate news is reflected in the market within five days lag.

It is found that the announcements belonging to Moody's have an influence on the investor behaviors and explain the volatility on the BIST100 index with two days lag. However, 
Moody's generally announce their report and corresponding action related to Turkey on Fridays and more importantly after the closing of the Turkish Stock Market. Therefore, investors could react to these announcements on Mondays which may be the cause of two days lag. It is interesting that the market tends to react earlier to the announcements of S\&P and Fitch. Anticipation or reaction in BIST100 appears one or two days before the announcement day.

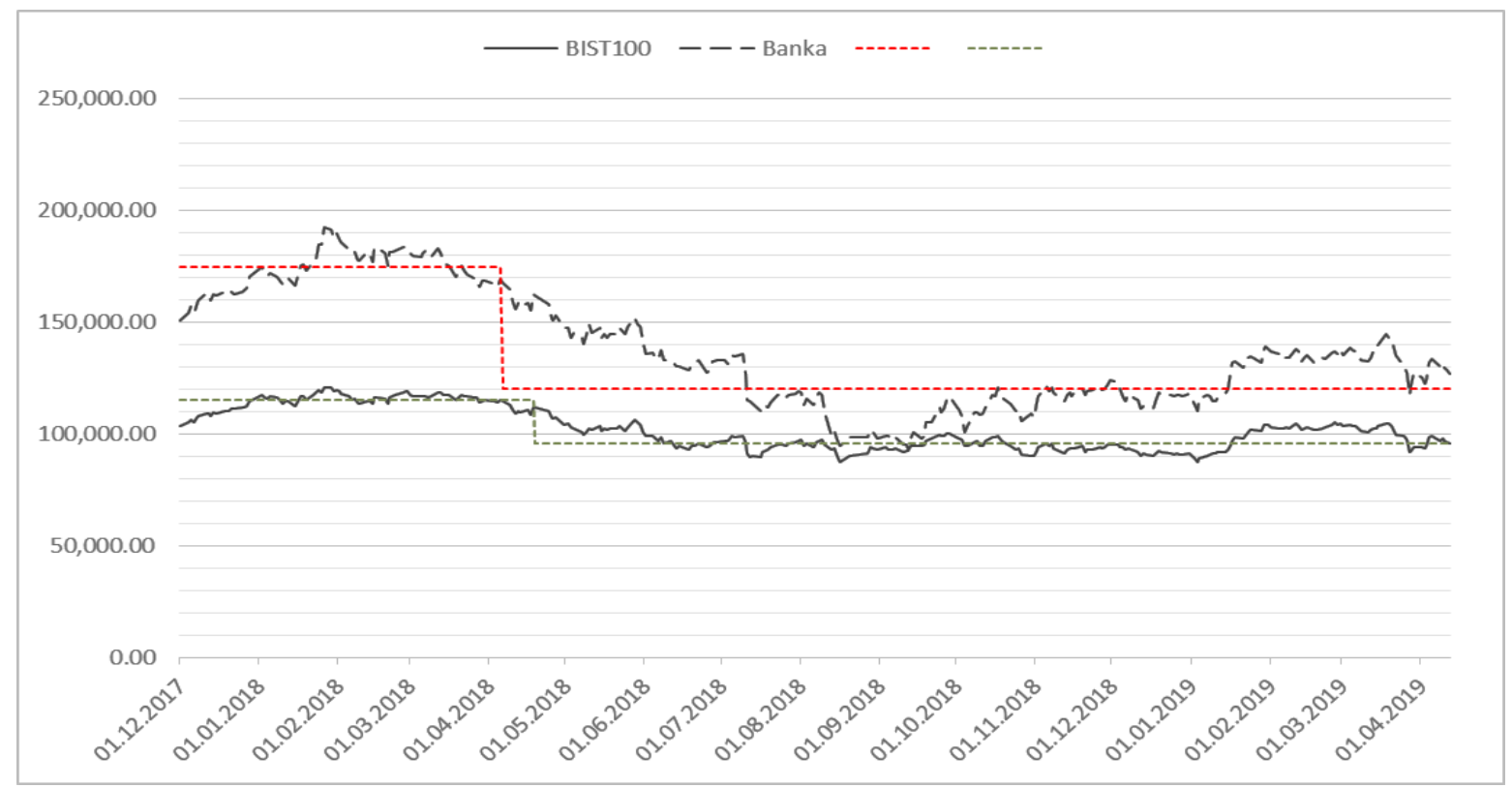

Figure 1: Structural Breaks in Indices

Table 3: Regression Analysis Results

\begin{tabular}{|c|c|c|c|c|}
\hline \multirow{3}{*}{$\begin{array}{l}\text { Variables } \\
\text { intercept }\end{array}$} & \multicolumn{2}{|c|}{$B I S T 100=\log y_{t}$} & \multicolumn{2}{|c|}{$X B A N K=\log y_{t}$} \\
\hline & \multirow{3}{*}{0,7223} & $S . E=0.1821$ & \multirow{3}{*}{0,3538} & $S . E=0.1324$ \\
\hline & & $t=3.9832$ & & $t=2.6956$ \\
\hline & & $p=0.0002$ & & $p=0.0068$ \\
\hline \multirow{3}{*}{$D_{t}$} & \multirow{3}{*}{0,0107} & $S . E=0.0051$ & \multirow{3}{*}{0,0109} & $S . E=0.0059$ \\
\hline & & $t=3.4269$ & & $t=2.3012$ \\
\hline & & $p=0.0007$ & & $p=0.0214$ \\
\hline \multirow{3}{*}{$\log y_{t-1}$} & \multirow{3}{*}{0,9371} & $S . E=0.0161$ & \multirow{3}{*}{0,9618} & $S . E=0.0123$ \\
\hline & & $t=59.3422$ & & $t=86.713$ \\
\hline & & $p=0.0001$ & & $p=0.0001$ \\
\hline \multirow{3}{*}{$u_{t}^{\text {news }}$} & \multirow{3}{*}{0,0102} & $S . E=0.0051$ & \multirow{3}{*}{-} & - \\
\hline & & $t=2.3367$ & & - \\
\hline & & $p=0.0213$ & & - \\
\hline
\end{tabular}




\begin{tabular}{|c|c|c|c|c|}
\hline \multirow{3}{*}{$q_{t-1}^{n e w s}$} & \multirow{3}{*}{0,0082} & $S . E=0.0042$ & \multirow{3}{*}{-} & - \\
\hline & & $t=2.2796$ & & - \\
\hline & & $p=0.0241$ & & - \\
\hline \multirow{3}{*}{$\pi_{t-5}^{n e w s}$} & \multirow{3}{*}{0,0094} & $S . E=0.0041$ & \multirow{3}{*}{0,0172} & $S . E=0.0071$ \\
\hline & & $t=2.6062$ & & $t=2.6942$ \\
\hline & & $p=0.00985$ & & $p=0.0068$ \\
\hline \multirow{3}{*}{$\operatorname{mood} y^{\prime} s_{t-2}^{n e w s}$} & \multirow{3}{*}{0,0172} & $S . E=0.0069$ & \multirow{3}{*}{0,0367} & $S . E=0.0141$ \\
\hline & & $t=2.2887$ & & $t=2.7436$ \\
\hline & & $p=0.0218$ & & $p=0.0071$ \\
\hline \multirow{3}{*}{ fitch $_{t+2}^{\text {news }}$} & \multirow{3}{*}{0.0192} & $S . E=0.0071$ & \multirow{3}{*}{0.0221} & $S . E=0.0126$ \\
\hline & & $t=2.8088$ & & $t=1.8652$ \\
\hline & & $p=0.0061$ & & $p=0.0641$ \\
\hline \multirow{3}{*}{$S \& P_{t+1}^{\text {news }}$} & \multirow{3}{*}{0.0241} & $S . E=0.0088$ & \multirow{3}{*}{-} & - \\
\hline & & $t=2.5614$ & & - \\
\hline & & $p=0.0111$ & & - \\
\hline \multirow{3}{*}{$S \& P_{t+4}^{\text {news }}$} & \multirow{3}{*}{0.0214} & $S . E=0.0087$ & \multirow{3}{*}{0.0691} & $S . E=0.0162$ \\
\hline & & $t=2.3423$ & & $t=4.2394$ \\
\hline & & $p=0.0121$ & & $p=0.0001$ \\
\hline$A d j_{-} R^{2}$ & 0.97 & & $A d j_{-} R^{2}$ & 0.98 \\
\hline
\end{tabular}

The information about the unemployment rate and capacity utilization rate of the manufacturing industry does not generate statistically significant results over the XBANK index. We also found statistically insignificant results for the announcements belonging to the S\&P rating agency considering the banking sector. Findings show that the other informational sources have a significant impact on the banking index, XBANK.

\section{CONCLUSION}

The effect of announcements on the financial market has attracted attention in the finance literature. Some of the studies in the literature have documented the existence of volatility in the short term following news released. In this study, the announcements and news are examined to measure their role in explaining volatility experienced by major indices in the Turkish Stock Market, XBANK, and BIST100.

Clustering the announcements according to their type does not generate significant results. 
However, when we examine the economic indicators and announcements by their source separately, the findings suggest that they have an impact and explain a portion of price volatility in the indices. The time of reaction of investors to the economic indicators changes within the range of one day to five days. We found that announcements of three different rating agencies carry informative value to the market and investors tend to respond differently to these announcements. More importantly, the reaction to the announcements released by S\&P and Fitch is reflected in the market one or two days before being publicly available.

Our conclusions go along with the findings of the studies done by Kosmidou et al. (2015) and Herath and Goonatilake (2007). These evidences from international stock exchanges are robust to effects of news on stocks. In addition to that, the findings of the studies regarding Turkish stock market are consistent with our main conclusions (Sarıül, 2015; Eyüboğlu\&Bulut, 2015; Gok\&Topuz, 2016).

We credence the literature by providing evidence from an emerging and little examined market. In the future, this study can be improved by analysing the effect of news in an intraday basis.

\section{Ethics Statement}

The study does not contain animals or humans as subjects.

\section{Author Contributions}

FC provided the necessary data, made a survey of studies related to the topic and wrote the manuscript. MN conducted all calculations and statistical analyses.

\section{Conflict of Interest}

The authors declare that they have no conflicts of interest.

\section{REFERENCES}

Andersson M., Overby L. J., \& Sebestyen S. (2009). Which News Moves the Euro Area Bond Market? German Economic Review, 10(1), 1-31.

Avc1, E., \& Gürsoy, Ö. (2017). The Impact of Sovereign Rating Changes on Turkish Stock Market Returns. International Research Journal of Applied Finance, 8(2), 120-128.

Balduzzi P., Elton E. J., \& Green T. C. (2001). Economic News and Bond Prices: Evidence from the U.S. Treasury Market. Journal of Financial and Quantitative Analysis, 36, 523-543.

Bartolini L., Goldberg L., \& Sacarny A. (2008). How Economic News Moves Markets. Current Issues in Economics and Finance, Federal Reserve Bank of New York, 14 (6).

Byström, H. (2016). Language, news and volatility. Journal of International Financial Markets, Institutions and Money, 42, 139-154.

Çekiç, A. İ., \& Gültekin, H. (2020). Macroeconomic Surprises and the Turkish Financial 
Market. In Applied Econometric Analysis: Emerging Research and Opportunities, 6088.

Ekinci, C., Akyildirim, E., \& Corbet, S. (2019). Analysing the dynamic influence of US macroeconomic news releases on turkish stock markets. Finance Research Letters, 31, 155-164.

Eyüboglu K., \& Bulut H. İ. (2015). Şirketlere özgü haberlerin hisse performansına etkisi: BİST30 şirketleri örneği. UIIIID-IJEAS, (16), 113-138.

Gok, I. Y., \& Topuz, S. (2016). The Impact Of The Domestic And Foreign Macroeconomic News Announcements On The Turkısh Stock Market. Financial Studies, 20(3).

Goonatilake, R., \& Herath, S. (2007). The volatility of the stock market and news. International Research Journal of Finance and Economics, 3(11), 53-65.

Green, T. C. (2004). Economic News and the Impact of Trading on Bond Prices. The Journal of Finance, 59 (3), 1201-1233.

Kim S., McKenzie M. D., \& Faff R. W. (2003). Macroeconomic news announcements and the role of expectations: evidence for US bond, stock and foreign exchange markets. Journal of Multinational Financial Management, 14, 217-232.

Kosmidou, K. V., Kousenidis, D. V., \& Negakis, C. I. (2015). The impact of the EU/ECB/IMF bailout programs on the financial and real sectors of the ASE during the Greek sovereign crisis. Journal of Banking \& Finance, 50, 440-454.

Kutan A. M., Muradoglu G., \& Sudjana G. (2011). IMF programs, financial and real sector performance, and the Asian crisis. Journal of Banking \& Finance, 36, 164-182.

Norden L., Weber M. (2004). Informational efficiency of credit default swap and stock markets: The impact of credit rating announcements, Journal of Banking \& Finance, 28(11), 2813-2843.

Pirgaip, B. (2017). Derecelendirme Notu Değişikliklerinin Borsa İstanbul (BIST) Pay Piyasası'na Etkileri. Ege Akademik Bakis, 17(3), 351-367.

Sarı̈ül H. (2015). Sendikasyon kredisi kullanım duyurularının bankaların hisse senedi getirilerine etkisi. Finansal Araştırmalar ve Çalışmalar Dergisi, 12 (7), 113-129.

Uslu H., Uzkaralar Ö. (2020). Arbitraj Fiyatlama Teorisinin Türkiye ekonomisinde geçerliliği: Küresel ekonomik kriz bağlamında ampirik bir analiz, Gazi İktisat ve İşletme Dergisi, 6(2), 179-195. 